\title{
L-asparaginase: An ultimate anti-neoplastic enzyme
}

\author{
VSSL Prasad Talluri*, M. Bhavana, MVS Mahesh Kumar, S. V. Rajagopal \\ Department of Biotechnology, GITAM Institute of Science, GITAM University, \\ Visakhapatnam - 530 045, Andhra Pradesh, India \\ *Mobile:- +918143762789, *Fax: +91-891 2790399 \\ *E-mail address: talluri.chowdary526@gmail.com
}

\begin{abstract}
The objective of the study described the importance of L-asparaginase and its importance in the field of medicine. Different types of enzymes are produced based on the adaptation to the environment where the living organisms live to tune the metabolic pathways according to their adapted changes. The enzymes present in various organs are produced by many cell types in multicellular organisms. Except ribosomes all other known enzymes are proteinaceous in nature. Lasparaginase is a potential therapeutic agent for acute lymphoblastic leukemia (ALL) and chronic myelogenous leukemia which is approved by FDA \& WHO. L-asparaginase catalyzes the deamination of L-asparagine to L-aspartic acid \& ammonia. Unlike normal cells, malignant cells require large amount of L-asparagine for protein synthesis and cell division. From this background the present review is an effort to gather the information on the mechanism, sources, molecular details and application of L-asparaginase enzyme.
\end{abstract}

Keywords: L-asparaginase; acute lymphoblastic leukemia; chemotherapeutic

\section{INTRODUCTION}

Controlled metabolism of bio-molecules such as carbohydrates, proteins, lipids etc is maintained by the living organisms. These metabolic reactions were catalyzed by various enzymes that control the metabolic pathway according to their needs.

Different types of enzymes are produced based on the adaptation to the environment where the living organisms live to tune the metabolic pathways according to their adapted changes. The enzymes present in various organs are produced by many cell types in multicellular organisms. Except ribosomes all other known enzymes are proteinaceous in nature and they are classified into six major classes based on their type of catalysis.

As it is true with proteins, disruption of native confirmation of enzyme by chemical and physical denaturing agents results in the loss of catalytic activity. The catalytic activity of enzymes depends on the integrity of their structure. Enzymes differ in their structure as they are coded by different genes and their molecular weight ranges from $12 \mathrm{kDa}$ to $1000 \mathrm{kDa}$. In addition to their specificity and catalytic efficiency, enzymes are also biodegradable without any toxicological problems. This property enables them to use in various commercial and 
pharmaceutical industries (Coral et al., 2003; Krishna and Lakshmi, 2005; Abu et al., 2006; Usama and Ali, 2008)

The sustenance of enzymes has been acknowledged well over a century. A Swedish chemist Jon Jakob Berzelius had studied the fundamentals and termed the catalytic reaction in the year 1835. The first enzyme was obtained in pure form achieved by James B. Sumner from Cornell University in 1926.

Microbes are the potential source for industrial and clinically important enzymes. The inability of the animal and plant sources to meet the demand of enzymes has lead to the increased interest in microbial sources. Microbial enzymes are preferred over plant or animal enzymes due to their economic production, consistency, high stability, ease of process modification and optimization. Microbial enzymes provide a greater diversity of catalytic activities and wide range of specificities to perform their biochemical reactions.

Most of the therapeutic and medicinally important enzymes are produced by microorganisms which have been commonly used for anti-inflammatory, thrombolytics or anticoagulants and oncolytics as replacement for metabolic deficiency. A major application of therapeutic enzymes is in the treatment of cancer. L-asparaginase has been widely used in chemotherapy in the field of medicine which has been proved to be a potential enzyme for the treatment of acute lymphocytic leukaemia (ALL) and Lymphosarcoma cancer. Microbial sources are most common for large scale production of L-asparaginase, because of the cost effective production.

\section{HISTORY OF L-ASPARAGINASE}

In 1953, Kidd noted that guinea pig serum had anti-tumour activity against two strains of murine lymphoma and a strain of lymphosarcoma in rats. Broome in 1963 first identified that the tumour inhibitory activity was due to of L-asparagianse present in the serum. In 1966, De lowery et al purified guinea pig serum and treated a boy with acute lymphocytic leukemia and got positive result. It catalyses the hydrolysis reaction of L-asparagine to aspartic acid and ammonia. The high concentration of ammonia (700-900 $\mu \mathrm{g} \%)$ results damage to central nervous system. This enzyme is produced by bacteria, plants and few particular animals. The most commonly used bacteria to produce L-asparaginase is Erwinia caratovora, Bacillus sp, Corynebacterium glutamicum, Pseudomonas stutzeri and E. coli. Lasparaginase produced from E.coli has excellent response to inhibit the activity of tumor cells (Mashburn \& Wriston 1963), and another one from E.chrysanthemi is also proved to be therapeutically active (James et al., 1970). L-asparaginase used for acute lymphoblastic Leukemia (ALL) in sequential chemotherapy shows a positive response (Whitecar et al., 1970). Suppression of immune response on antibody formation as well as allograft immunity by L-aspiraginase from bacteria was reported by Friedman \& chakrabarty 1971.

When L-asparaginase was intravenously injected into patients, it is primarly distributed in the plasma. The concentration of the enzyme in the plasma is long as 23 days after cessation of the enzyme treatment. The plasma half life of L-asparaginase varies from eight to thirty hours in different patients. The concentration of L-asparaginase in cerebrospinal fluid was $<1 \%$ that of plasma level and only trace amount was found in the urine. Acute lymphocytic leukemia (ALL) is the most common cancer in children (4-6 yrs). L-asparaginase is a potential therapeutic agent for ALL and chronic myelogenous leukemia which is approved by FDA \& WHO. L-asparaginase catalyzes the deamination of L- 
asparagine to L-aspartic acid \& ammonia. Unlike normal cells, malignant cells require large amount of L-asparagine for protein synthesis and cell divison. Thus, its depletion by Lasparaginase causes destruction of tumor cells out of which only E-coli and Erwinia cavatovora are used commercially.

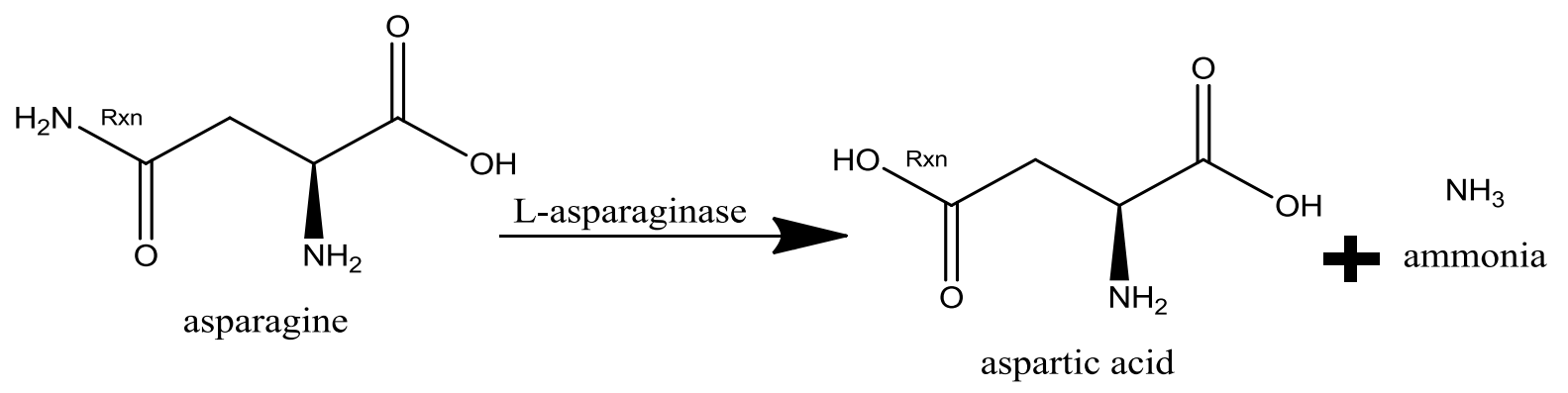

Figure 1. Hydrolysis of asparagine into aspartic acid and ammonia.

Various enzymes have been used as drugs for the treatment of Acute Lymphoblastic Leukemia (ALL) and Lymphosarcoma Cancer (Head et al 1995). L-asparaginase amidohydrolase; EC 3.5.1.1 catalyzes the breakdown of L-asparagine to L-aspartate and ammonia $\left(\mathrm{NH}_{3}\right)$ and to a minor extent also catalyzes the hydrolysis of L-glutamine to Lglutamate. Bacterial L-asparaginases have been identified as two types: type I and type II by Campbell et al., 1967. Type I L-asparaginases are expressed constitutively in the cytoplasm and catalyze the hydrolysis of both L- Asparagine and L-Glutamine, whereas type II Lasparaginase are expressed under anaerobic conditions in the periplasmic space of the bacterial membranes and display higher specificity for L-Asparagine hydrolysis (Campbell et al., 1967; Cedar and Schwartz, 1968) .

Screening of micro-organisms that produce L-asparaginase was done by $\mathrm{pH}$ and dyebased rapid plate assay method (Gulati et al. 1997). It takes $24 \mathrm{hrs}$ and $48 \mathrm{hrs}$ to get the promising result for bacteria and fungi respectively. The quantative results of enzyme formation in culture broths were obtained after the assay. L-asparaginase which produces strains was identified due to color change in the media by phenol red indicator. Phenol red at acidic $\mathrm{pH}$ is yellow in color and at alkaline $\mathrm{pH}$ it turns pink, thus a pink zone is formed around the microbial colonies that produce L-asparaginase.

\section{MECHANISM OF ANTINEOPLASTIC ACTION OF L-ASPARAGINASE}

Normal cells have the asparagine synthetase for synthesis of asparagine in their diet and asparagine is an inessential amino acid for normal cells. The gene which codes for asparagine synthetase was located on Chromosome number 7 (7q21.3) in humans (Andrulis I. L. et al. 1990). Due to the lack of asparagine synthetase tumor cells do not have the capability to produce asparagine hence it is a key amino acid for those tumor cells (Kiriyama et al. 1989). RNA and protein synthesis is repressed in the absence of asparagine (Goody H. E. and Ellem K. A. 1975) and as a result cell cycle arrest and apoptosis is induced in murine leukemia cell lines (Ueno T. et al. 1997). L-asparaginase level in serum must be $>100 \mathrm{IU} / \mathrm{L}$ to achieve the total asparagine depletion in the human circulation (Boos J. et al. 1554). 5-diazo-4-oxo-LNorvaline and 5-chloro-4-oxo-L-Norvaline are effective inhibitors of asparagine synthetase (Handschumacher 1977). 
<smiles>N[C@@H](CC(=O)CCl)C(=O)O</smiles>

5-chloro 4-oxo L-norvaline<smiles>[N-]=[N+]=CC(=O)C[C@H](N)C(=O)O</smiles>

5-diazo 4-oxo L-norvaline

Figure 2. Inhibitors for asparagine synthetase.

The depletion of L-asparaginase results in cytotoxicity for leukemia cells. Therapeutic enzymes differ from other drugs in two main features i.e., the enzymes act on their target site with a high affinity and great specificity; secondly the substrate is converted into a desired product by their catalytic activity (Michel 2003). Most of the bacterial strains have capacity to produce L-asparaginase. L-asparaginase produced by Escherichia coli and Erwinia chrysantemi have been used as chemotherapeutics in Acute Lymphoblastic Lymphoma (Mashburn 1964). Several brand name of L- asparaginase are available in the market such as ERWINASE, CLOLAR, LEUKINE, ONCASPAR, ARRANON, KIDROLASE and ELSPAR<smiles>O=C(O)CC(=O)C(=O)O</smiles>

Oxalo acetate
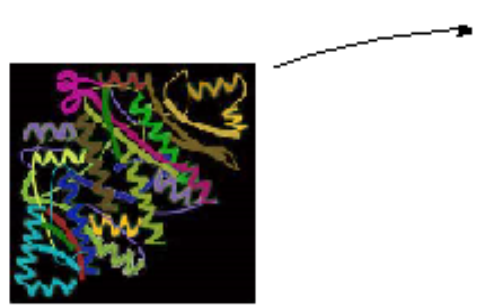<smiles>N[C@@H](CC(=O)O)C(=O)O</smiles>

Aspartate

Figure 3. Synthesis of L-asparagine from oxalo acetate by asparagine synthetase using transaminase. 


\section{SOURCES FOR L-ASPARAGINASE}

\section{1. L-asparaginase from bacteria}

Sources such as Escherichia coli, Netrval, 1977; Erwinia aroideae, Tiwari and Dua, 1996 have been reported to have L-asparaginase. Gram negative bacteria such as Vibrio succinogenes (E. Albanese and K. Kafkewitz, 1978), Thermus thermophilus (Prista et al., 2001) have played a crucial role in most of the work. L-asparaginase has also been studied from marine bacteria, as they are considered to be an important source of bioactive enzymes.

Marine bacteria are halophilic in nature and can be used industrially. L-asparaginase production has also been reported in Pseudomonas flourescens (Mardashev et al 1975) whereas its production in Staphylococci has been described by Mickucki et al. 1977. Most of the Industrial scientists as well as Microbiological researchers have preferred to work with Tetrahymena pyriformis.

Tsirka 1990, because its enzyme activity has been found in stationary phase of growth and most of the activity has been associated with the ER Trianfolliou et al., 1988. L-asparaginases produced from a new Erwinia $s p$. has been reported by Bokotky and Bezbaruah 2002.

Table 1. L-asparaginase from different bacterial source.

\begin{tabular}{|c|c|c|}
\hline Sl. No. & $\begin{array}{c}\text { Name of the Bacteria producing } \\
\text { L-asparaginase }\end{array}$ & Reference \\
\hline 1 & Pencillium sp. & Krishna \& Nibha 2012 \\
\hline 2 & Staphylococcus capitis & Satish et al. 2012 \\
\hline 3 & Fusarium equiseti & Hosamani \& kaliwal 2011 \\
\hline 4 & Thermus thermophilus & Pritsa et al. 2001 \\
\hline 5 & Enterobacter aerogenes & Mukherjee et al. 2000 \\
\hline 6 & E. cloaceae & Nawaz et al. 1998 \\
\hline 7 & Helicobacter pylori & Stark et al. 1997 \\
\hline 8 & Erwinia aroideae & Tiwari \& Dua 1996 \\
\hline 9 & P. stutzeri & Manna et al. 1995 \\
\hline 10 & Bacillus sp. & Mohapatra et al. 1995 \\
\hline 11 & E. chrysanthemi & Moola et al. 1994 \\
\hline 12 & E. carotovora & Maladkar et al. 1993 \\
\hline 13 & S. aureus & Rozalska \& Mikucki 1992 \\
\hline 14 & Streptococcus albus & Reddy \&eddy 1990 \\
\hline
\end{tabular}




\begin{tabular}{|c|c|c|}
\hline 15 & Tetrahymena pyriformis & Tsirka 1990 \\
\hline 16 & Corynebacterium glutamicum & Mesas et al. 1990 \\
\hline 17 & Klebsiella pneumonia & Reddy \& Reddy 1990 \\
\hline 18 & B. polymyxa & Nefelova et al. 1978 \\
\hline 19 & Escherichia coli & Netrval 1977 \\
\hline 20 & T. aquaticus & Curran et al. 1976 \\
\hline 21 & Pseudomonas ovalis & Badr \& Foda 1976 \\
\hline 22 & Vibrio succinogenes & Disteasio et al. 1976 \\
\hline 23 & Mycobacterium phlei & Pasterzak \& Szymona 1976 \\
\hline 24 & Citrobacter sp. & Bascomb et al. 1975 \\
\hline 25 & B. mesentericus & Tiul panova et al. 1972 \\
\hline 26 & Serratia marcescens & Rowly \& Wriston 1967 \\
\hline
\end{tabular}

\section{2. L-asparaginase from yeast}

L-asparaginases that are presently in use are obtained from various members of the Yeast family especially Saccharomyces cervisiae which is encoded by the ASP3 gene (Bon et al., 1977). L-asparaginase was also isolated from the cell culture broth of Candida utilis (Kil et al., 1995). Its production has also been reported from Pichia polymorpha, isolated from Egyptian Soils by Enrichment method (Foda et al., 1980).

Table 2. L-asparaginase from different yeast source.

\begin{tabular}{|c|c|c|}
\hline S. No. & $\begin{array}{c}\text { Name of the Yeast producing } \\
\text { L-asparaginase }\end{array}$ & Reference \\
\hline 1 & Rhodotorula sp & Foda et al. 1980 \\
\hline 2 & Pichio polymorpha & Foda et al. 1980 \\
\hline 3 & C. guilliermondii & $\begin{array}{c}\text { Stepanyan \& Davtyan } \\
1988\end{array}$ \\
\hline 4 & Candida utilis & Kil et al. 1995 \\
\hline 5 & Rhodosporidium toruloides & $\begin{array}{c}\text { Ramakrishnan } \text { et al. } \\
1996\end{array}$ \\
\hline 6 & Saccharomyces cerevisiae & Bon et al. 1997 \\
\hline
\end{tabular}




\section{3. L-asparaginase from fungi}

Wide range of fungal strains are efficient producers of L-asparaginase. Streptomyces karnatakensis is a species novel which procuring L-asparaginase. L-asparaginase produced from strain of $A$. terrus is isolated by decomposing the vegetable substrate by Ali et al., 1994. L-asparaginase from fungi, from Mangrove ecosystem of Bhitarkanika by Gupta \& sarita 2009 has also been reported.

Table 3. L-asparaginase from different Fungal source.

\begin{tabular}{|c|c|c|}
\hline S. No. & $\begin{array}{c}\text { Name of the Fungi producing } \\
\text { L-asparaginase }\end{array}$ & Reference \\
\hline 1 & A.tamarii & Verma et al 1976 \\
\hline 2 & Aspergillus nidulans & Drainas \& Drainas 1985 \\
\hline 3 & Cylidrocapron obtusisporum & Raha et al. 1990 \\
\hline 4 & A.terreus & Ali 1994 \\
\hline 5 & Mucor sp. & Mohapatra et al. 1997 \\
\hline 6 & A.niger & Mishra 2006 \\
\hline 7 & A.oryzae & Hendriksen et al. 2009 \\
\hline
\end{tabular}

\section{4. L-asparaginase from actinomycetes}

L-asparaginase from the actinomycete strain LA-29 source was isolated from the gut contents of the fish, Mugil cephalus of the Vellar estuary by Sahu et al. which was reported to have significant enzyme activity. Dhevagi et al reported the isolation of marine actinomycetes from the Parangipettai and Cochin coastal areas of South India. Gunasekaran et al. 1995 reported L-asparaginase production by Nocardia sp. Production of intracellular and extracellular Asparaginase from Streptomyces longsporusflavus F-15 has been described by Abdel-Fatah et al. 1998. Mostafa acknowledged L-asparaginase from two streptomyces species i.e., S.venezuelae and S.karnatakensis. L-asparaginase activity from cell free extracts of Thermusactinomyces vulgaris was identified by Mostafa \& Ali 1983.

Table 4. L-asparaginase from different Actinomycetes source.

\begin{tabular}{|c|c|c|}
\hline S. No. & $\begin{array}{c}\text { Name of the Actinomycetes } \\
\text { producing L-asparaginase }\end{array}$ & Reference \\
\hline 1 & Streptomyces karnatakensis & Mostafa 1979 \\
\hline 2 & S. venezuelae & Mostafa 1979 \\
\hline 3 & S. collinus & Mostafa \& Salama 1979 \\
\hline
\end{tabular}




\begin{tabular}{|c|c|c|}
\hline 4 & Thermoactinomyces vulgaris & Mostafa \& Ali 1983 \\
\hline 5 & Noccardia sp. & Gunasekaran et al. 1995 \\
\hline 6 & Streptomyces longsporusflavus & Abdel-Fatah et al. 2002 \\
\hline 7 & Actinomyces sp. & Sahu et al. 2007 \\
\hline 8 & Streptomyces tendae & $\begin{array}{c}\text { Kavitha \& Vijaylakshmi } \\
2010\end{array}$ \\
\hline 9 & Streptomyces gulbargensis & Amena et al. 2010 \\
\hline
\end{tabular}

\section{RESULT AND DISCUSSION}

\section{1. Asparaginase from Plant}

Green chillies Capsicum annum L. and tamarind Tamarindus indica has been reported to have abundant amounts of L-asparaginase. Mozeena Bano and V.M. Sivaramakrishnan in 1980 used sources to isolate the enzyme. Seed of Pisum sativum was also used as a source of L-asparaginase isolated by Lea and Miffin whose activity is dependent on the presence of $\mathrm{K}^{+}$ ions. Different species of Solancaceae and Fabaceae were screened for the activity of Lasparaginase. Withania somnifera was identified as L-asparaginase producer out of 34 different species. Co-occurrence of both subtypes of L-asparaginase has been seen in Arabidopsis (Bruneau L. et al. 2006). Immobilization and anti-tumor effect from two different seeds i.e., Vicia faba and Phaseoulus vulgaris was screened for L-asparaginase (Fyaid et al. 2012).

Table 5. L-asparaginase from different plant source.

\begin{tabular}{|c|c|c|}
\hline S. No. & $\begin{array}{c}\text { Name of the Plants producing } \\
\text { L-asparaginase }\end{array}$ & Reference \\
\hline 1 & Pisum sativum & Wriston 1982 \\
\hline 2 & Lupin araboreus & Borek et al. 1999 \\
\hline 3 & Sphagnum fallax & Heeshen et al. 1996 \\
\hline 4 & Pinus pinaster & Bell \& Adams 2004 \\
\hline 5 & Lupin angustiplius & Borek et al. 2004 \\
\hline 6 & Pinus radiate & Bell \& Adams 2004 \\
\hline 7 & Arabidopsis thaliana & Bruneau et al. 2006 \\
\hline 8 & Lupinus luteus & Michalska et al. 2006 \\
\hline 9 & Withania somnifera L & Oza et al. 2009 \\
\hline
\end{tabular}




\section{2. Activators and Inhibitors}

There are a few elements which affect the action of the enzyme. Few inhibit the enzyme while some activate the enzyme reaction and increase the activity up to many folds. The metal ions, such as $\mathrm{Fe}^{2+}, \mathrm{Cu}^{2+}, \mathrm{Zn}^{2+}, \mathrm{Ni}^{2+}$ and $\mathrm{Hg}^{2+}$ greatly inhibit the enzyme activity, while metal chelators like EDTA, $\mathrm{CN}^{-}$, cysteine, etc., enhance the activity which shows that the enzyme is not a metalloprotein (Raha S. K. et al. 1990 22).

\section{3. Recombinant L-asparaginase}

Epitope studies on Erwinia chrysanthemi using polyclonal antisera and hexapeptides from rabbits and mices (Moola et al. 1994) were performed. Removal of immunodominant epitiopes on enzymes by site targeted mutagenesis resulted in reduced immunogenicity while the enzyme activity was remained unchanged due to decrease in binding with antibodies (Harry et al. 1986). Asparaginase from Helicobacter pylori is expressed in E.coli and is directed to the stable synthesis of catalytically active asparaginase with low level of glutaminase specificity which can be purified using single chromatographic stage. Human asparaginase-like protein 1 hASRGL1 has been expressed in E.coli BL21 DE3 cells and enzymatic characterization of the protein has been completed. hASRGL1 is the Ntn hydrolase in Thr168 that acts as the necessary N-terminal nucleophile for intramolecular processing and catalysis (Cantor et., 2009). The gene of Flammulina velutipes asparaginase FvNase was isolated and over expressed in E. coli with L-asparagine hydrolyzing activity of $16 \mathrm{U} / \mathrm{ml}$ in crude extract i.e. 5 times higher than its L-glutamine hydrolyzing ability with optimum $\mathrm{pH}-7$ which is tolerant towards high temperature and sodium chloride concentration (Eisele et al., 2010).

\section{4. Side effects of L-asparaginase}

Diabetes Mellitus has been observed in a patient with lymphoblastic leukemia while treating with L-asparaginase and dexamethasone (Alves et al.,2007). After introducing polyethylene glycol conjugated asparaginase in an 18 year old female patient with acute lymphoblastic leukemia anaphylaxis and superior vena cava syndrome was observed. A 7 year old Thai boy suffering from acute lymphoblastic leukemia developed pancreatic panniculitis when administered with L-asparaginase (Chiewchengchol et al. 2009). Cholesterol level and triglyceride level increase during asparaginase treatment in children with acute lymphoblastic leukemia (Cohen et al 2010). Lipid abnormalities return to normal in children upon completion of the asparaginase treatment. Hypersensitivity reactions are caused by some antineoplastic agents caused by L-asparaginase (Cortijo-Cascajares et al 2012).

\section{5. L-asparaginase: an enzyme of medicinal value}

L-asparaginase is a medicinally significant enzyme used for treatment in all pediatric regimens and in the majority of adult treatment protocols. The foremost proposed application of L-asparaginase as an injectable drug and its abolition in blood involves its monitoring in treated cancer patients especially ALL patients to avoid recurrence (Masao 1986). An inhibitor of human asparagines synthetase suppresses the proliferation of leukemic cell line. It is an efficient agent used for the treatment of acute lymphoblastic leukemia, when Lasparaginase resistant MOLT-4 cells were cultured in the presence of L-asparaginase. The formulation of PEG-L-asparaginase by the conjugation of $E$. coli L-asparaginase with PEG is 
a preparation of decreased immunogenicity and decreased circulating half-life. Among the number of treatments of acute leukemia such as steroids, radiation therapy, severe combined treatments including bone marrow or stem cell transplants etc, chemotherapy is most preferable. The drugs most frequently employed for treatment includes, asparaginase, daunorubicin, cyclophosphamide, mercaptopurine, methotrexate etc (Jain et al., 2012). Many scientists have described the role of L-asparaginase in the treatment of cancer and cancer biology. A huge amount of investment has been made on the enzyme to discover the new effective ways.

\section{6. Applications of L-asparaginase}

The enzyme L-asparaginase has the chemotherapeutic property against the tumor cells. It is an effective curable agent against the treatment of acute lymphoblastic leukemia and lymphosarcoma. The principle behind the use of L-asparaginase as an anti-tumor agent is that it takes advantage of the fact that all leukemic cells are incapable of synthesizing the nonessential amino acid asparagines of their own. It is very essential for the growth of the tumor cells, whereas normal cells can synthesize their own asparagine; thus leukemic cells require high amounts of asparagine. L-asparaginase has a significant role in food industry. Acrylamide is a significant toxic agent that causes neurotoxicity in humans and is present in ample amounts in food items which are heat-derived, containing some reducing sugars. Its formation is the result of a heat inducing reaction between the free amino acid asparagine and carbonyl group of reducing sugars like glucose, which is named as the Maillard reaction. Hence L-asparaginase has an important application in the food industry like baking food industry. The formation of acrylamide is significantly reduced by the hydrolyzing of asparagine catalyzed by the enzyme. The reported reduction in acrylamide content is about 90 \% (Mario Sanches et al. 2007). An experiment was conducted by Kukurova K et al. (2009) on dough resembling traditional Spanis rosquillas in which they considered the different parameters which influence the reaction, formation of acrylamide, temperature/time profile of frying process, moisture, sugars, amino acids, acrylamide, and some indicators of Maillard reaction. They got a reduction of $96-97 \%$ in acrylamide content at different levels of asparagine (Kukurova K et al. 2009).

\section{CONCLUSIONS}

Enzymes are in huge demand as chemotherapeutic agents against many terrible diseases. The enzymes can diminish the ability for cancer cells to attach to healthy organs or tissue. L-asparaginase is a potential therapeutic agent for acute lymphoblastic leukemia (ALL) and chronic myelogenous leukemia which is approved by FDA \& WHO. L-asparaginase found to be very promising agent in the treatment of acute lymphoblastic leukemia and other kinds of cancer. Normal tissue can synthesize L-asparagine but the cancer cells, particularly malignant and carcinoma cells require external source of L-asparaginase for their growth and multiplication. In the presence of L-asparaginase, the tumor cells deprived of an important growth factor and they failed to survive. Thus the enzyme L-asparaginase can be used as a chemotherapeutic agent for the treatment of ALL (mainly in children) as a potent antitumor or anti-leukemia drug. Moreover application of L-asparaginase in the food industry for the elimination of cancer-causing acrylamide from baked food has been one of the eminent discoveries of modern time. Thus a lot more is needed to investigate about this astounding enzyme. 


\section{Acknowledgement}

The authors are thankful to GITAM university management for providing necessary facilities for carry out this work. Prasad acknowledges Shanthi Lanka for the help of English proof reading. We apologize to those whose papers and critical studies were not cited or were not discussed at length in this article because of space limitation.

\section{References}

[1] Abdel-Fttah Y. R., Olama Z. A., Process Biochemistry 38(1) (2002) 115-122.

[2] Abu Sayem S. M., Alam M. J., Mozammel Hoq Md., Pakisthan Acad. Sci. 43 (2006) 257-262.

[3] Amena S., Vishalakshi N., Prabhakar M., Dayanand A., Lingappa K., Braz. J. Microbiol. 41 (2010) 173-178.

[4] Badr E. I., Foda M. S., Zentralbl Bakteriol Parasetenkd Infektionskr Hyg. 131 (1976) 489-496.

[5] Bascomb S., Banks G. T., Skarstedt M. T., Journal of General Microbiology 91 (1975) 1-16.

[6] Bon E. P., Appl. Biochem. Biotechnol. 63/65 (1997) 203-212.

[7] Boos J., Int J Clin Pharmacol Ther 35 (1997) 96-98.

[8] Borkotaky B., Bezbaruah R. L., Folia Microbiologica 47(5) (2002) 473-476

[9] Broome J., Nature 171 (1961) 1114.

[10] Bruneau L., Chapman R., Marsolais F., Planta 224 (2006) 668-679.

[11] C. Alves, C. Chaves, M. Souza., Endocrinol Metabol. 51(4) (2007) 635.

[12] C. Liu, J. D. Kawedia, C. Cheng, D. Pei, C. A. Fernandez, X. Cai., Clinical utility and implications of asparaginase antibodies in acute lymphoblastic leukemia. Leukemia., Apr 9, 2012, [Epub ahead of print].

[13] Campbell H., Mashburn L., Boyse E., Old J. L., Biochemistry 6 (1967) 721-730.

[14] Cantor J. R., Stone E. M., Chantranupong L., Georgiou G., Biochemistry 48(46) (2009) 11026-11031.

[15] Cedar H., Schwartz J., Journal of Bacteriology 96(6) (1968) 2043-2048.

[16] Coral G., Arikan B., Unaldi M. N., Guvenmez H., Annals of microbiology 53 (2003) 491-498.

[17] Curran M. P., Daniel R. M., Guy R. G., Morgan H. W., Arch. Biochem. Biophys. 241 (1985) 571-576.

[18] D. Chiewchengchol, S. Wanankul, N. Noppakun, Pediatric Dermatology 26(1) (2009) 47.

[19] Drainas D., Drainas C., Eur. J. Biochem. 151 (1985) 591-593.

[20] E. Albanese, K. Kafkewitz, Applied and Environmental Microbiology 36(1) (1978) 2530.

[21] Foda M. S., Zedan and Hashem, Acta. Microbiol. Pol. 29 (1980) 343-352.

[22] Friedman M., A review. J. Agric. Food Chem. 51 (2003) 4504-4526.

[23] Goody H. E., Ellem K. A., Biochim Biophys Acta 383 (1975) 30-39.

[24] Gulati R., Saxena R. K., Gupta R., Letters Applied Microbiology 24 (1997) 23-26.

[25] Gunasekaran S., McDonald L., Manavathu M., Manavathu E., Gunasekaran M., Biomedical Letters 52(207) (1995) 197-201.

[26] H. Cohen, B. Bielorai, D. Harats, A. Toren, O. P. Hamiel, Pediatric Blood and Cancer 54(5) (2010) 703. 
[27] Handschumacher R. E., Methods Enzymol. Vol.46 (1977) 432-435.

[28] Hendriksen H. V., Kornbrust B. A., Ostergaard P. R., Stringer M. A., J. Agric. Food Chem. 57 (2009) 4168-4176.

[29] Hosamani R., Kalival B. B., International Journal of Drug Discovery 3(2) (2011) 8899.

L. Andrulis, M. T. Barrett, Molecular and Cellular Biology 9(7) (1989) 2922-2927.

[30] Kidd J. G., J. Exp. Med. Vol.98 (1953) 565-581.

[31] Kil J. O., Kim G. N., Park I., Biotechnol. Biochem. Vol.59 (1995) 749-750.

[32] Kiriyama Y., Kubota M., Takimoto T., Kitoh T., Tanizawa A., Akiyama Y., Mikawa H., Leukemia 3 (1989) 294-297.

[33] Krishna Suresh Babu Naidu., Lakshmi Devi K., African Journal of Biotechnology 8 (2005) 724-726.

[34] Kukurová K., Morales F. J., Bednáriková A., Ciesarová Z., Mol. Nutr. Food Res. 53 (2009) 1532-1539.

[35] M. H. Kang, Y. H. Kang, B. Szymanska, U. W. Kalak, M. A. Sheard, T. M. Harned, Blood Journal 110(6) (2007) 2057.

[36] Maladkar N. K., Singh V. K., Naik S. R., Hindustan Antibiotic Bull. Vol.35 (1993) 7786.

[37] Manna S., Sinha A., Sadhukhan R., Chakrabarty S. L., Curr. Microbiol. 30 (1995) 291298.

[38] Mardashev S. R., Nikoaev A. Y., Sokolov N. N., Kozlov E. A., Kutsman M. E., Bokhimiya 40(5) (1975) 984-989.

[39] Mashburn L., Wriston J., Arch Biochem Biophys. 105 (1964) 450.

[40] Mesas J. M., Gil J. A., Martin J. F., J. Gen. Micro Biol. 136 (1990) 515-519.

[41] Michalska K., Bujacz G., Jaskolski, M., J. Mol. Biol. 360 (2006) 105-116.

[42] Michel D., Stefan S., Alina F., Xavier R., Brigitte N., Patrick L., Yves B., Alain R., Anne-Marie M., Etienne V., Jacques O., Noel P., Blood 99 (2002) 2734-2739.

[43] Mickucki J., Szarapinska K. J., Krzeminski Z., Zentralbl. Bakteriol. Parasetenkd. Infektionskr. Hyg. 132(2) (1997) 135-142. 1997

[44] Mishra A., Appl. Biochem. Biotechnol. Vol.135 (2006) 33-42.

[45] Mohapatra B. R., Bajpuji M., Banerjee U. C., Cytobios. 92 (1997) 165-173.

[46] Moola Z. B., Biochem. J. 302 (1994) 921-927.

[47] Mostafa S. A., Bacteriol (Naturiviss). 134 (1979) 343-351.

[48] Mostafa S. A., Ali O. A., Zbl. Microbiol. 5 (1983) 397-404.

[49] Mukherjee J., Appl. Microbiol. Biotechnol. 53(2) (200) 180-184.

[50] Nawaz M. S., Zhang D., Khan A. A., Cerniglia C. E., Applied Microbiology and Biotechnology 50(5) (1998) 568-572.

[51] Nefelova M. V., Ross. Prikl. Biokhim Mikrobiol. 14 (1978) 510-514.

[52] Netrval J., Folia Microbiologica 22(2) (1997) 106-116.

[53] Nibha Gupta, SaritaJayanti Dash, Uday Chand Basak, As. Pac J. Mol. Bio. Biotechnol 17(1) (2009) 27-30.

[54] Oza V. P., Trivedi S. D., Parmar, P. P., Subramanian R. B., J Integr Plant Biol. Vol.51 (2009) 201-206

[55] Pritsa A. A., Kyriakidis D. A., Mol. Cell. Biochem. 216 (2001) 93-101.

[56] R. Jain, K. U. Zaidi, Y. Verma, P. Saxena., People's Journal of Scientific Research. 5(1) (2012). 
[57] Raha S. K., Roy S. K., Dey S. K., Chakrabarty S. L., Biochem. Int. Vol.21 (1990) 9871000.

[58] Ramakrishnan M. S., Joseph R., Canadian Journal of Microbiology 42(4) (1996) 316325.

[59] Reddy V. K., Reddy S. M., Indian J Microbiol. 30 (1990) 81-83.

[60] Rowly B., Wriston J. C., Biochem Biophys Res Commun. 28 (1967) 160-171.

[61] Rozalska M., Mikucki J., Acta Microbiologica Polonica 41(3-4) (1992) 145-150.

[62] Sahu M. K., Poorani E., Sivakumar K., Thangaradjou T., Kannan L., J. Environ. Biol. 28 (2007) 645-650.

[63] Sanches M., Barbosa J. A. R. G., de Oliveira R. T., Abrahão Neto, J. A., Polikarpov I., Acta Cryst. D59 (2003) 416-422.

[64] Stark R. M., Sulemain M. S., Hsant I. J., Greenman J., Millari M. R., J Med Microbiol. 46 (1997) 793-800.

[65] Stepnyan K. R., Davtyan M. A., Biologicheskii Zhurnal Armenii 41 (1988) 599-603.

[66] Tiul' Panova E. S., Microbiologika 41 (1972) 423-429.

[67] Tiwari N., Dua R. D., Indian J. Biochem Biophys. 33 (1996) 371-376.

[68] Trianfolliou D. J., Georgatsos J. G., Kryiankidis D. A., Mol and cell biochem 81(1) (1988) 43-51.

[69] Tsirka S. A., Kyriakidis D. A., Molecular and Cellular Biochemistry 95(1) (1990) 7788.

[70] Ueno T., Ohtawa K., Mitsui K., Kodera Y., Hiroto M., Matsushima A., Inada Y., Nishimura H., Leukemia 11 (1997) 1858-1861.

[71] Usama F. Ali, Research Journal of Agriculture and Biological Sciences 4 (2008) 886891.

[72] Verma N., Kumar K., Kaur G., Anand S., Crit. Rev. Biotechnol. 27 (2007) 45-62. 